\title{
ANALYZING THE INFLUENCE OF DIATOMITE AND MINERAL FERTILIZERS ON THE FEATURES OF CADMIUM-CONTAMINATED URBAN LAWNS
}

\author{
D.D. Gosse ${ }^{1}$, V.I. Vasenev ${ }^{2,3}$, A.K. Afonina ${ }^{2}$, \\ A.S. Shepeleva ${ }^{2,3}$ \\ ${ }^{1}$ Moscow State University \\ Leninskie gori str., 1, building 46, Moscow, Russia, 119991 \\ ${ }^{2}$ RUDN University \\ Miklukho-Maklay str., 8/9, Moscow, Russia, 117198 \\ ${ }^{3}$ Russian State Agrarian University \\ Timiryazevskaya str., 49, Moscow, Russia, 127550
}

\begin{abstract}
Contamination with heavy metals is among key anthropogenic pressures, experienced by urban lawns. It results in depletion of their environmental quality and functions. Implementation of fertilizers, containing silicon, is a promising approach to increase urban lawns' sustainability to heavy metals' pollution. Based on the field experiment, an influence of cadmium contamination on the chemical features and biomass quality of modeled urban green lawn ecosystems was studied. We demonstrated an increase of cadmium consumption by biomass on the second year of observations as the result of diatomite implementation together with mineral fertilizers. Both total sugar and disaccharides' content in biomass was $15-20 \%$ higher for the contaminated plots where diatomite was implemented together with mineral fertilizers, compared to the uncontaminated control. This evidences a positive effect of the implemented reclaiming on stress tolerance of the green lawns.
\end{abstract}

Key words: heavy metals, pollution, urban lawn ecosystems, environmental functions, silicon, field experiment, sugar, stress tolerance

\section{INTRODICTION}

Urbanization is a global trend of the 21st century [22]. Land conversion into urban results in semi-natural and artificial ecosystems, characterized by specific vegetation and soils $[5 ; 9 ; 34]$. Urban lawns play a key role in the structure of urban ecosystems. Many studies report on the substantial areas, covered by urban lawns in settlements (up to $40 \%$ unsealed areas) [33;29] and the diversity of their functions. Along with the obvious ornamental function, lawns increases the deposition of fine dust, participate in filtration of surface waters, contribute to carbon sequestration and together with plantations increase the effect of noise absorption [31]. The specific features of urban soils and soil constructions under lawn ecosystems were also investigated $[1 ; 16]$, in particular the high content of organic carbon and nutrients, lightweight, particle size distribution, increased average temperatures (especially in summer), intense emission of greenhouse gases such as $\mathrm{CO}_{2}$, and in some cases $\mathrm{N}_{2} \mathrm{O}$ and $\mathrm{CH}_{4}$ [24;27;2]. The implementation of environmental and aesthetic functions of urban lawns largely depends on their resilience to ongoing anthropogenic pressures in the urban environment.

The main types of anthropogenic impact on urban lawns are compaction, salinization and pollution $[9 ; 10]$. Among them, the cadmium contamination is one of the most negative impacts, as this metal has a high toxicity to living organisms even at low 
concentrations $[12 ; 7 ; 15]$. So far, there is no consensus on the effects of cadmium on the properties and functions of soils and vegetation. For example, depending on the concentration, salts of cadmium had an inhibitory and a stimulating effect on the microbiological activity of soils and growth of plant biomass [35; 17]. At the same time, cadmium along with lead, arsenic, and mercury is among the pollutants of the first class of danger. Environmental and health risks associated with cadmium pollution, raises the importance of selecting the optimal fertilizers and reclaiming substances (meliorates), reducing the negative impact on soil, plants and the environment [11].

Agrochemical methods of reclamation of polluted soils are mainly based on i) the transfer of heavy metal cations to the inaccessible for plants forms by increasing the physico-chemical adsorption capacity of soils; ii) the creation of conditions for the deposition of metals in the soluble for the antagonism of ions manifestation. The application of fertilizers and meliorates containing silicon, is a promising method of increasing the stability of plants in conditions of contamination [21]. An ability of siliceous materials (diatomite, zeolites) to provide a beneficial effect on the resistance of plants to abiotic stresses (drought, salinity) is widely accepted [20; 28]. Many studies claim the impact of silicon on the toxicity of heavy metal compounds in higher plants, for example barley $[23 ; 26 ; 6]$, maize [25] and vegetables [32]. At the same time, the effectiveness of silicon-containing meliorates on urban lawns contaminated with cadmium, remains poorly studied [4].

The aim of this study was to examine an influence of silicon-containing meliorates of diatomite in combination and without mineral fertilizers on the uptake and redistribution of cadmium in urban lawns, as well as on the quality of model biomass in urban lawns.

\section{MATERIALS AND METHODS}

Taking into account the high spatial diversity of lawn ecosystems and the abundance of different factors of possible influence, a multi-factor field experiment was carried out. The experiment was conducted in the period from 15 July 2012 to 15 September 2013 at the soil experimental station of Lomonosov Moscow State University (LMSU) $\left(55^{\circ} 42^{\prime} \mathrm{N} ; 3^{\circ} 31\right)$. The experiment included model turf ecosystem, representing 'constructozems' (urban constructed soils), with growing lawn grass mixture. The sand-peat mixture was used to create the organic layer of the constructozems. The mixture included $30 \%$ of bank sand and $70 \%$ of lowland peat. The principal chemical features of the mixture were in accordance with the requirements of the certification system "Moscow Environmental Registry" (MER). Lawn grass mixture was chosen in accordance with existing standards (Rules.., 2002). Each experimental plot covered $2 \mathrm{~m}^{2}$. Lawn grass was seeded in May 15, 2012. Cadmium was applied in the form of salt $\mathrm{Cd}\left(\mathrm{NO}_{3}\right)_{2} \times 4 \mathrm{H}_{2} \mathrm{O}$ at the rate $19.8 \mathrm{~g}$ per plot. The diatomite was added in the amount of $120 \mathrm{~g}$ per plot. Among the mineral fertilizers diammonium phosphate $(\mathrm{N}: \mathrm{P}: \mathrm{K}=$ $10: 25: 25)$ was used (48 g per plot) and ammonium nitrate $(34 \% \mathrm{~N})$ was implemented (21.2 g per plot). The final ratio of $\mathrm{N}: \mathrm{P}: \mathrm{K}$ in mineral fertilizers was $60: 60: 60 \mathrm{~kg}$ of active agent per 1 ha. Fertilizers, cadmium and diatomite were added 3 days before sowing, with minimal surface sealing. In the second year of the study, mineral fertilizer were added on April 25, diatomite and salt of cadmium were not re-introduced. 
The following treatments were studied: I) control (without cadmium and fertilizers) (K); II) cadmium with fertilizer (KCd); III) cadmium and diatomite (CdД); IV) cadmium and fertilizers (CdNPK); and V) cadmium, diatomite and mineral fertilizers (CdNPKD). As an external control uncontaminated plots with the introduction of diatomite (KD), mineral fertilizers (KNPK) and their joint introduction (KNPKD) were considered. All the options were in three replicas. Meteorological conditions were monitored according to the weather station of LMSU, and were later adjusted according to RusFluxNet monitoring network (Vasenev et al., 2014). During growing season irrigation and mechanical weed control were performed. Grass samples were collected 8 times in 2 vegetation period with limited frame $\left(0.25 \mathrm{~m}^{2}\right)$, two replicas per plot to account for the biomass and further research in the laboratory. The 2nd and 4th mowing were selected from each year since the plants in these periods are the least susceptible to influence of uncontrollable factors in the external environment. Mowed part of lawn grasses were weighed and fixed for 10 minutes at $90{ }^{\circ} \mathrm{C}$, then dried at room temperature. All measurements were carried out in three replicas (Fig. 1).

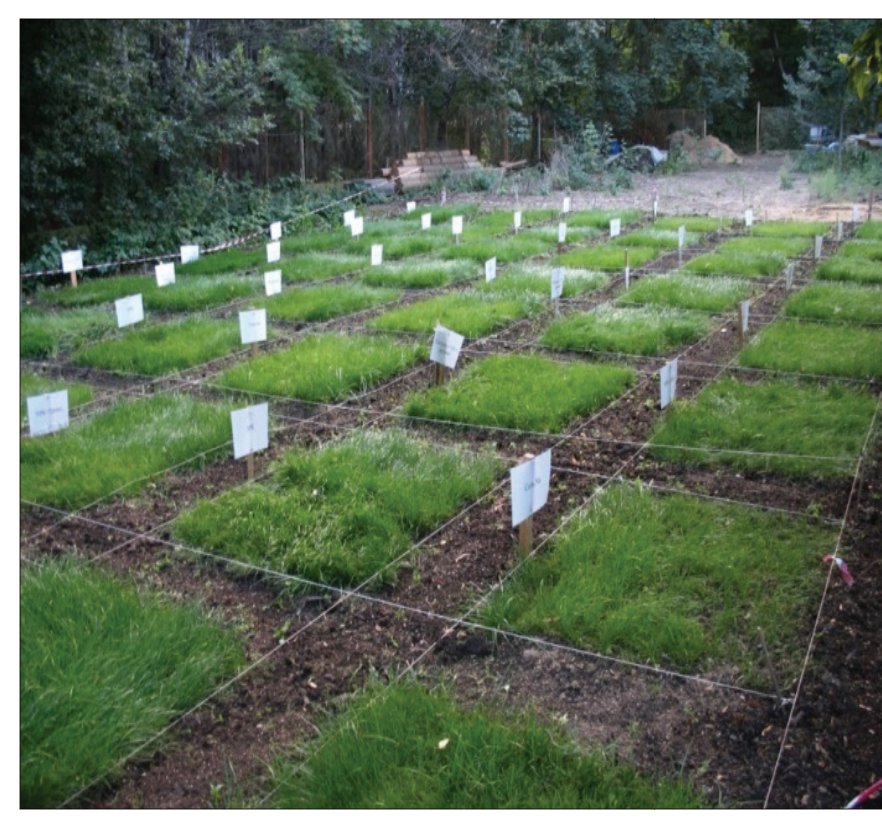

A

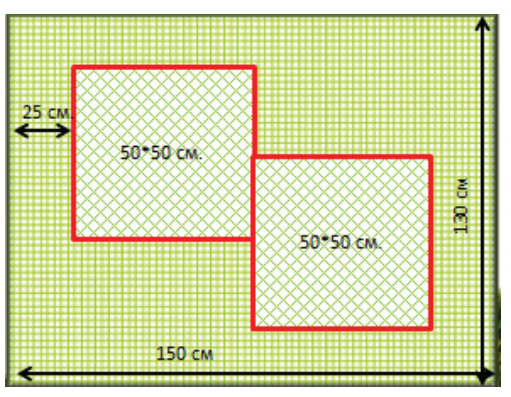

B

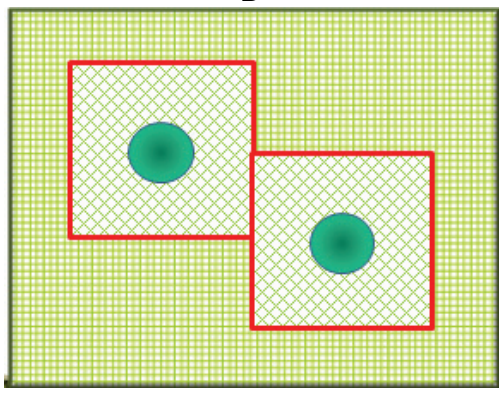

C

Fig. 1. Sampling scheme for biomass (B) and soil (C) in multi-factor field experiment $(A)$

Contents of total nitrogen, phosphorus, potassium were analyzed in the biomass samples by conventional methods [14]. Atomic-absorption method after dry combustion and dissolving the ash with a mixture of nitric and hydrochloric acids was implemented to analyze the content of $\mathrm{Cd}$ in plants. The content of total sugars, mono - and disaccharides were determined by the method of Bertrand with picric acid. All the measurements were carried out in three replicas. The results were processed and presented in MS Excel 2010. 


\section{RESULTS AND DISCUSSIONS}

\section{Climatic conditionsof the experiment}

The meteorological conditions over the growing period of the lawn were similar to the long-term trends. Dynamics of air temperature and precipitation were, on average, corresponding to long-term data, which allows considering the results of the experiment as representative. On average, the summer-autumn period of 2013 was more humid than the same period in 2012. The average annual temperature in 2013 was $1.5^{\circ} \mathrm{C}$ higher due to warmer winters, however, statistically significant differences of air temperature in the summer-autumn period between the years was not identified (Fig. 2).

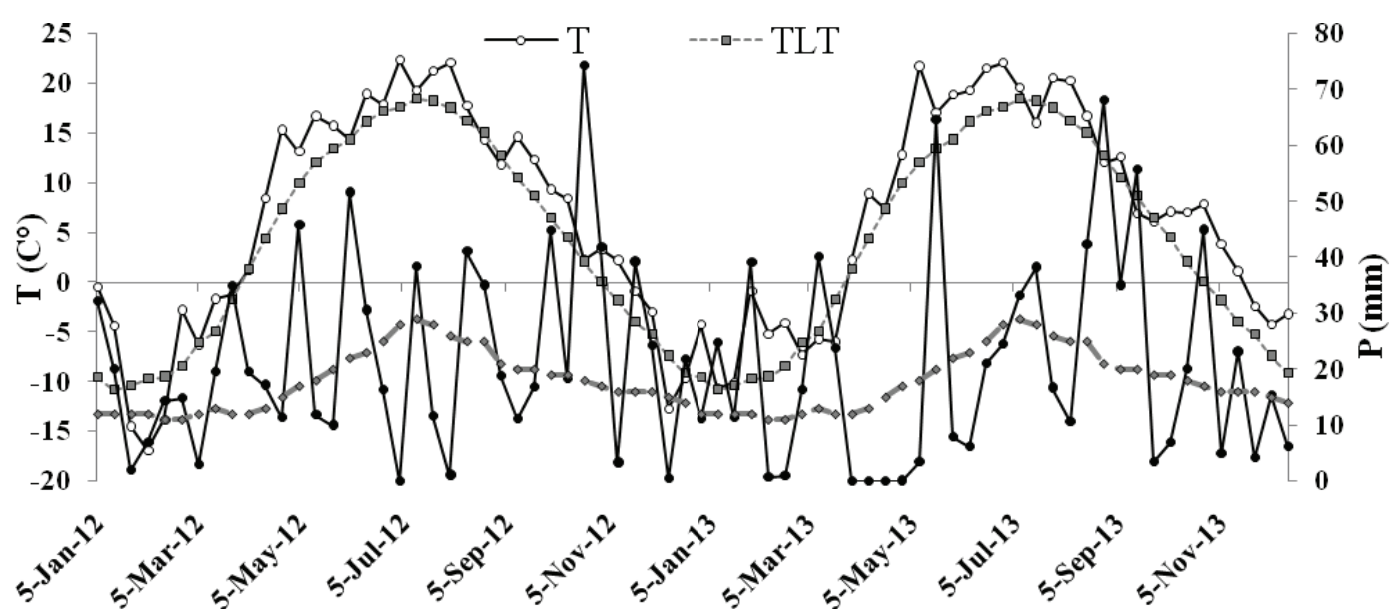

Fig. 2. Air temperatures $(T)$ and precipitation $(P)$ for the whole period of the experiment in comparison to the long-term trends (TLT) and precipitation (PLT)

\section{The effect of contamination with cadmium on the grass biomass properties}

The introduction of cadmium led to the increase in the grass biomass. A significant difference with the control was shown in 2012 (especially in the second harvest, when it exceeded the control 14 times). In 2013, an increase of cadmium content was obtained for the biomass of contaminated sites (particularly in the fourth mowing - 2.5 times compared to 2012). The absolute values of the average content of cadmium in the samples of biomass from the contaminated sites were similar, however the relative content compared to the control increased threefold (Table 1). The differences between the content of macro elements in biomass of the polluted and control sites were not significant.

In 2013, a silicon content in cadmium-contaminated variants increased $20 \%$ compared to control in the second mowing, and 2.5 times in the fourth mowing. The increase in silicon content in 2013 compared to 2012 was found for the control as well (38 times), however, for the contaminated samples the annual growth was much more significant (in 11-13 times). Apparently, in the process of growth and maturation of the lawn the accumulation of silicon in cell walls occurred. Silicon participates in the formation of skeletal parts of plants, strengthens the stem and root system. 
Gosse D.D. et al. Analyzing the Influence of Diatomite and Mineral Fertilizers on the Features...

Dynamics in contents of macro elements and cadmium

in the biomass of the studied lawn ecosystems

(the second and fourth harvests (H2 and H4, respectively))

\begin{tabular}{|c|c|c|c|c|c|c|c|c|c|c|}
\hline \multirow[t]{2}{*}{ Treatment } & \multicolumn{2}{|c|}{$\mathrm{N}_{\text {tot }}(\%)$} & \multicolumn{2}{|c|}{$\mathrm{P}_{2} \mathrm{O}_{5}(\%)$} & \multicolumn{2}{|c|}{$\mathrm{K}_{2} \mathrm{O}(\%)$} & \multicolumn{2}{|c|}{ Si (\%) } & \multicolumn{2}{|c|}{$\begin{array}{c}\text { Cd } \\
(\mu \mathrm{g} / \mathrm{kg} \text { dry matter })\end{array}$} \\
\hline & $\mathrm{H} 2$ & $\mathrm{H} 4$ & $\mathrm{H} 2$ & $\mathrm{H} 4$ & $\mathrm{H} 2$ & $\mathrm{H} 4$ & $\mathrm{H} 2$ & $\mathrm{H} 4$ & $\mathrm{H} 2$ & $\mathrm{H} 4$ \\
\hline \multicolumn{11}{|c|}{2012} \\
\hline $\mathrm{K}$ & 3.36 & 1.86 & 1.45 & 1.28 & 3.46 & 3.27 & 0.06 & 0.05 & 0.53 & 2.15 \\
\hline $\mathrm{KCd}$ & 2.79 & 2.7 & 1.41 & 1.11 & 3.11 & 4.13 & 0.06 & 0.05 & 8.34 & 3.01 \\
\hline CdD & 2.7 & 1.78 & 1.4 & 1.16 & 3.29 & 2.9 & 0.05 & 0.05 & 9.41 & 6.05 \\
\hline CdNPK & 3.04 & 6.34 & 1.43 & 1.24 & 3.40 & 4.13 & 0.06 & 0.05 & 16.28 & 5.96 \\
\hline CdNPKD & 3.17 & 2.31 & 1.55 & 0.91 & 3.35 & 2.98 & 0.06 & 0.06 & 4.41 & 5.81 \\
\hline KD & 2.61 & 3.51 & 1.34 & 1.06 & 2.99 & 3.34 & 0.06 & 0.05 & 1.55 & 3.43 \\
\hline KNPK & 3.11 & 4.34 & 1.38 & 1.25 & 3.43 & 2.92 & 0.06 & 0.05 & 2.06 & 2.09 \\
\hline KNPKD & 2.88 & 3.37 & 1.48 & 1.18 & 3.62 & 3.63 & 0.06 & 0.05 & 1.45 & 2.76 \\
\hline \multicolumn{11}{|c|}{2013} \\
\hline $\mathrm{K}$ & 1.92 & 2.28 & 1.49 & 0.32 & 3.04 & 4.1 & 0.56 & 0.21 & 0.1 & 0.1 \\
\hline KCd & 2.23 & 2.55 & 0.13 & 0.41 & 2.77 & 3.4 & 0.71 & 0.73 & 3.13 & 8.25 \\
\hline CdD & 2.13 & 2.38 & 1.12 & 0.28 & 2.93 & 3.8 & 0.79 & 0.73 & 2.13 & 6.88 \\
\hline CdNPK & 1.81 & 2.20 & 2.22 & 0.32 & 2.66 & 3.70 & 0.52 & 0.78 & 1.50 & 4.00 \\
\hline CdNPKD & 2.16 & 2.18 & 0.82 & 0.18 & 2.51 & 3.4 & 0.64 & 0.88 & 0 & 9.38 \\
\hline KD & 2.22 & 2.8 & 1.5 & 0.24 & 3.12 & 3.5 & 0.61 & 0.72 & 0 & 0 \\
\hline KNPK & 1.86 & 2.97 & 1.19 & 0.3 & 3.19 & 3.9 & 0.58 & 0.41 & 0 & 0 \\
\hline KNPKD & 1.68 & 2.21 & 1.01 & 0.23 & 2.87 & 4.1 & 0.7 & 0.29 & 0 & 0 \\
\hline
\end{tabular}

Surprisingly, the cadmium pollution didn't decrease total biomass and in some cases even stimulated the growth. This corresponds to literature data that show that some doses of heavy metals are able to have a complicated and stimulating effect on the plants conditions [17]. Besides, considering the deficit of microelements in the investigated constructozems, cadmium could have a stimulating effect on plants, replacing some metals with similar chemical properties [8]. The cadmium pollution didn't result in significant changes in the amount of sugars in biomass, but the proportion of disaccharides in the biomass of the autumn harvest has decreased $15 \%$, which may indicate a stressed condition of the lawn grasses (Fig. 3).

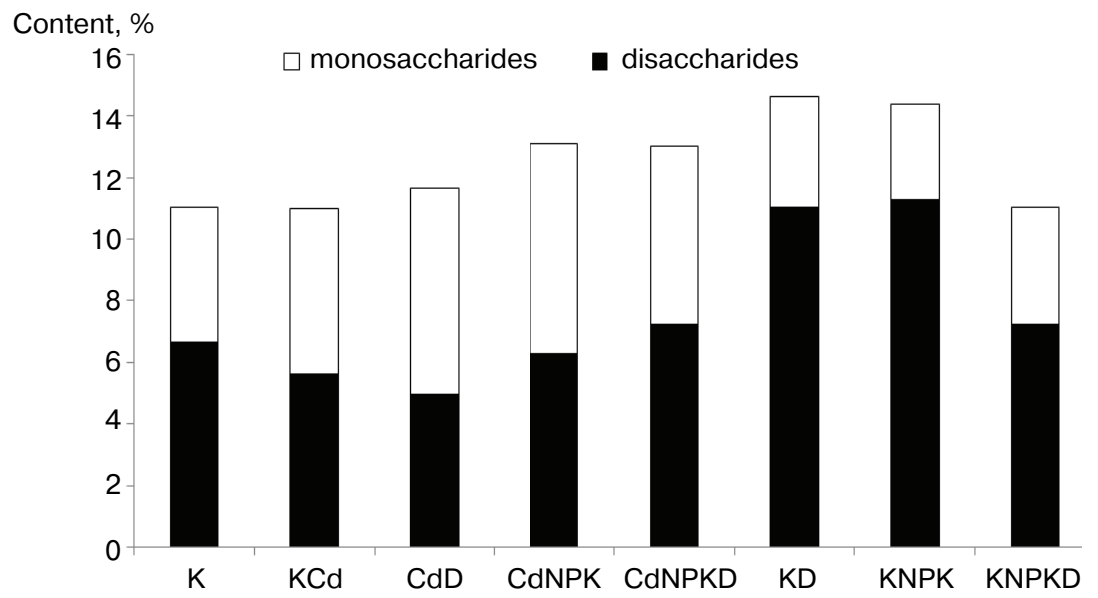

Fig. 3. The total sugar content, mono- and disaccharides in the biomass of experimental plots in autumn (3rd and 4th) mowing of 2013 

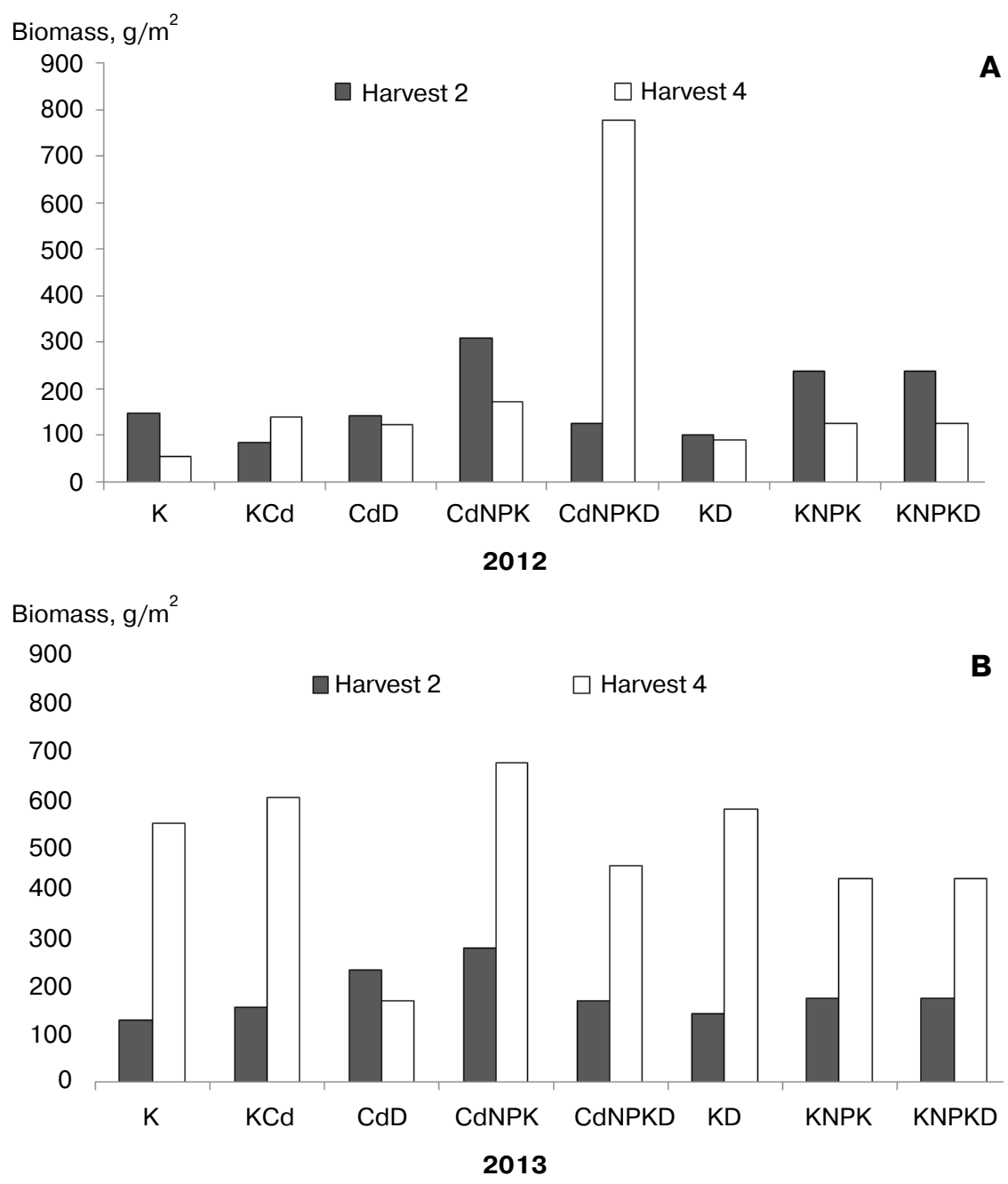

Fig. 4. Dynamics of the biomass of experimental plots in $2012(A)$ and $2013(B)$, respectively

In general, the average biomass of the lawns in 2013 increased 5-8 times, which could be explained both by favourable weather conditions and the maturation of the lawn. The increase of biomass from contaminated sites in 2013 compared to 2012 was less than for the control (Fig. 4).

\section{Effect of diatomite on the lawn properties that had been contaminated with cadmium}

The introduction of diatomite in the contaminated areas contributed to the significant increase of biomass (50-70\%). The exception was in 4th mowing of 2013, which recorded unusually high biomass of the polluted area without diatomite, $15-20 \%$ higher than the control (Fig. 4). The total number of sugars in the biomass plots $\mathrm{CdD}$ was $6 \%$ higher than for $\mathrm{KCd}$, however, the proportion of disaccharides was less than $10-15 \%$ and $20-25 \%$ in comparison with the polluted and non-polluted control respectively, 
for individual harvests and in average over the season (Fig. 3). Apparently, the introduction of diatomite in the specified concentrations without chemical fertilizers did not contribute to improving the sustainability of biomass to anthropogenic pressures, or the effect occurred later than the second year after application. Analyzing the effects of diatomite on the content of macro elements in biomass of contaminated sites, most notable is the decrease in the $\mathrm{N}$ content, which is probably associated with the "growth dilution", as well as the fact that the diatomite as silicon sorption type fertilizerthat absorbs nitrate and ammonia $\mathrm{N}$ from root layer. The phosphorus content in the biomass plots $\mathrm{CdD}$ was in average higher and potassium - lower than for $\mathrm{KCd}$ plots, however, a general reduction of elements content from 2012 to 2013 was also observed. The introduction of diatomite led to the increase in the silicon content in the biomass of contaminated sites, especially in 2013. The cadmium content in biomass of contaminated sites, where diatomite was introduced, was significantly higher than without introduction (up to $100 \%$ on the 4th mowing), but in 2013, a statistically significant effect of the introduction of diatomite on contaminated sites was not found (Table 1).

\section{Dynamics of grass biomass properties contaminated with cadmium, with the introduction of diatomite and mineral fertilizers}

Mineral fertilizers contributed to a visible increase in biomass (up to 4 times) compared with the control and contaminated sites (the exception was in 4th cut of 2013). Total sugar content increased by 13 and $19 \%$ compared to $\mathrm{CdD}$ and $\mathrm{KCd}$. Moreover, an average content of sugars in the biomass in the autumn (3rd and 4th harvests exceeded those in unpolluted control by $18 \%$. The application of mineral fertilizers without diatomite on contaminated sites has also contributed to the increase in the proportion of disaccharides. At the same time, the maximum effect was achieved with the joint application. The content of disaccharides in the biomass plot CdNPKD increased by 12, 15 and $27 \%$ compared to the $\mathrm{KCd}$, and CdNPK and CdD respectively (Fig. 3). The content of nitrogen, phosphorus and potassium in the biomass of the polluted area with the introduction of diatomite with mineral fertilizers is higher than without those, but less than in the control plot.

\section{CONCLUSION}

Heavy metals pollution and, in particular, cadmium contamination is one of the most common pressures experienced by urban lawns, which can reduce the effectiveness of their environmental and aesthetic functions. It was shown that the cadmium pollution has led to a significant increase in the content of heavy metal and to reduction of macroelements' content in biomass of grasses, however the total biomass did not change significantly. In the result of the introduction of diatomite the uptake of cadmium by plants increased. When adding diatomite with the mineral fertilizers in the second year of the experiment the cadmium content in biomass increased $20-50 \%$. The introduction of diatomite in combination with mineral fertilizers increases both the total sugar content, 
and the content of disaccharides in the biomass, which indicates the increase of plant resistance to stress is revealed. At the same time, the use of meliorates together with mineral fertilizers stimulated the removal of cadmium by crop plants. This pattern is promising for the development of technologies for phytoremediation of urban soils contaminated with heavy metal, which is very important for modern cities.

\section{Acknowledgements}

The study was supported by the RFBR projects №NK 15-54-53117 and № NK 15-34-70003.

(C) D.D. Gosse, V.I. Vasenev,

A.K. Afonina, A.S. Shepeleva, 2016

\section{REFERENCES}

[1] Belobrov V.P. and Zamotaev I.V. Soil and green lawns of the sports and technical facilities. M.: GEOS, 2007, P. 115-203 (in Russian).

[2] Vasenev V.I. Agrochemical and microbiological characteristics of constructsem of Moscow and Moscow region / Agrochemical Vestnik, № 4, 2011. P. 1213-1218 (in Russian).

[3] Vasenev I.I., Vasenev V.I., Valentini R. Agro-environmental objectives of the analysis of greenhouse gas fluxes and soil carbon pools under the regional environmental monitoring RUSFLUXNET. Agroecology. No. 1, 2014. P. 8-12 (in Russian).

[4] Verkhovtsev N.V., Soloviev S.A., Soloviev A.S. Protection of lawn grass with natural siliceous agroores. Agrochemistry. No. 9, 2014. P. 87-96 (in Russian).

[5] Gerasimova M.I., Stroganova, M.N., Mozharova, N.V., T.V. Prokof'eva, Anthropogenic soils: Genesis, geography, recultivation. Textbook. Smolensk: Oikumena, 2003. P. 268 (in Russian).

[6] Egorov V.S., Gosset, D.D., Dzerzhinskaya, A.A. Effect of fertilizers on the content and behavior of cadmium in the system soil-plant on sod-podzolic soils. Problems of Agrochemistry and ecology. No. 9, 2009. P. 27-31 (in Russian).

[7] Ilyin V.B., Syso A.I. Microelements and heavy metals in soils and plants of Novosibirsk region. SB RAS, 2001 (in Russian).

[8] Koshkin E.I. Fiziologiya and sustainability of agricultural crops. Drofa, 2010 (in Russian).

[9] Kurbatovaa A.S., Bashkin V.N., Barannikova, Y.A., Gerasimov S.G., Nikiforova E.V., Reshetina E.V., Savelyev V.A., Savin D.S., Smagin A.V., Stepanov A.L. Ecological functions of urban soils. Moscow-Smolensk: Magenta, 2004. P. 232 (in Russian).

[10] Makarov O.A., Redko V.M., Guchok M.V. Ecological-economic and ecological-bonitirovka assessment of soil and land in the Moscow region. M.: MAKS Press, 2011. P. 262 (in Russian).

[11] Obukhov A.I., PlekhanovaI. O., Kutukova J.D., Afonina E.V. Heavy metals in soils and plants of Moscow // Ecological studies in Moscow and the Moscow region. M., 1990. S. 148-162 (in Russian).

[12] Ovcharenko M.M. Heavy metals in the system soil-plant-fertilizer. Avtoref. dis. ... doctor. agricultural sciences. M., 2000. P. 34 (in Russian).

[13] Rules for the establishment, maintenance and protection of green plantings of the city of Moscow. Moscow Government Resolution of September 10. 2002. No. 743. Moscow (in Russian). 
[14] Practicum on agricultural chemistry (edited by Mineev V.G.). 2001. Publishing house MSU, Moscow (in Russian).

[15] Revich B.A. Environmental epidemiology. M.: Akademiya, 2004 (in Russian).

[16] Smagin V.A. The theory and practice of designing of soils. M.: Publishing house MSU, 2012 (in Russian)

[17] Titov A.F., Talanova V.V., Kaznina N.M., Laidinen G.F. The resistance of plants to heavy metals. Petrozavodsk: Karelian research center of RAS, 2007. 172 p. (in Russian).

[18] Tuldukov V.A., Cobozin I.V., ParahinV.B. Lawn sience and landscaping of populated areas. M.: Kolos, 2002 (in Russian).

[19] Castaldi, S., F.A Rutigliano and A. Virzo de Santo. Suitability of soil microbial parameters as indicators of heavy metal pollution. Water Air Soil Poll 158: 21-35, 2014.

[20] Epstein E. Silicon. Annual Review of Plant Physiology and Plant Molecular Biology, 50, 1999. P. $641-664$

[21] Epstein E. Silicon: its manifold roles in plants. Annals of Applied Biology. 155, 2009. P. $155-160$.

[22] FAO // Climate-smart agriculture. Sourcebook, 2013. E-ISBN 978-92-5-107721-4.

[23] Horiguchi, T., Morita, S., Mechanism of manganese toxicity and tolerance of plants. VI. Effect of silicon on alleviation of manganese toxicity of barley. J. Plant Nutr 10, 2299e2310, 1987.

[24] Kaye, J.P., I.C. Burke, A.R. Mosier, and J.P. Guerschman. Methane and nitrous oxide fluxes from urban soils to the atmosphere. Ecol Appl 14:975—981, 2004.

[25] Liang, Y.C., Wong, J.W.C., Wei, L. Silicon-mediated enhancement of cadmium tolerance in maize (Zea mays L.) grown in cadmium contaminated soil. Chemosphere 58, 475e 483 , 2005.

[26] Liang, Y.C., Yang, C.G., Shi, H.H. Effects of silicon on growth and mineral composition of barley grown under toxic levels of aluminum. J. Plant Nutr 24, 229e243, 2001.

[27] Lorenz, K. and R. Lal. Biogeochemical C and N cycles in urban soils. Environment International: 35,2009 . P. $1-8$.

[28] Ma J.F. Silicon requirement in rice. III Silicon in Agriculture Conference, Ed. G.H. Korndorfer, 52-61. Uberl`andia, Brazil: Universidad Federal de Uberl^andia, 2005.

[29] Milesi, C. and S.W Running. Mapping and modeling the biogeochemical cycling of turf grasses in the United States. Environ Manage 36, 2005. P. 426- 438.

[30] Pickett, S.T.A., M.L. Cadenasso, J.M. Grove et al. Urban ecological systems: scientific foundations and a decade of progress. J Environ Manage 92, 2011. P. 331-362.

[31] Raciti S.M., Hutyra L.R., Rao P. and Finzi A. Inconsistent definitions of "urban" result in different conclusions about the size of urban carbon and nitrogen stocks. Ecological Applications. 22, 2012. P. 1015-1035.

[32] Rogalla, H., Ro"mheld, V. Role of leaf apoplast in silicon-mediated manganese tolerance of Cucumissativus L. Plant Cell Environ 25, 549-555, 2002.

[33] Svirejeva-Hopkins, A., H.J. Schellnhuber and V.L. Pomaz. Urbanized territories as a specific component of the global carbon cycle. Ecol Model 173, 2004. P. 295-312.

[34] Pickett, S.T.A., M.L. Cadenasso, J.M. Grove, P.M. Groffman, L.E. Band, C.G. Boone, W.R. Burch, C.S.B. Grimmond, J. Hom, J.C. Jenkins, N.L. Law, C.H. Nilon, R.V. Pouyat, K. Szlavecz, P.S. Warren and M.A. Wilson. 2008. Beyond urban legends: an emerging framework of urban ecology, as illustrated by the Baltimore Ecosystem Study. BioScience 58: $139-150$.

[35] Castaldi, S., F.A Rutigliano and A. Virzo de Santo. 2004. Suitability of soil microbial parameters as indicators of heavy metal pollution. Water Air Soil Pollution 158: 21-35. 
DOI: $10.22363 / 2312-797 X-2016-4-75-84$

\title{
АНАЛИЗ ВОЗДЕЙСТВИЯ ДИАТОМИТА И МИНЕРАЛЬНЫХ УДОБРЕНИЙ НА СВОЙСТВА ГОРОДСКИХ ГАЗОНОВ, ЗАГРЯЗНЕННЫХ КАДМИЕМ
}

\author{
Д.Д. Госсе ${ }^{1}$ В.И. Васенев ${ }^{2,3}$, А.К. Афонина ${ }^{2}$, \\ А.С. Щепелева ${ }^{2,3}$ \\ ${ }^{1}$ Московский государственный университет имени М.В. Ломоносова \\ Ленинские горы, 1, Москва, Россия, 119991 \\ ${ }^{2}$ Российский университет дружбы народов \\ ул. Миклухо-Маклая, 8/2, Москва, Россия, 117198 \\ ${ }^{3}$ РГАУ-МСХА имени К.А. Тимирязева \\ ул. Тимирязевская, 49, Москва, Россия, 127550
}

Загрязнение тяжелыми металлами - одна из наиболее распространенных нагрузок, испытываемых городскими газонами, которая приводит к снижению их экологического качества и выполняемых ими функций. Применение кремнийсодержащих удобрений и мелиорантов - перспективный способ повышения устойчивости газонных экосистем в условиях загрязнения. На основании полевого мелкоделяночного опыта изучено воздействие загрязнения кадмием на химические свойства и качество биомассы модельных газонных экосистем. Показано увеличение поглощения кадмия биомассой растений на второй год внесения диатомита на фоне минеральных удобрений. Как общая сумма сахаров, так и содержание дисахаридов в биомассе загрязненного участка с внесением диатомита на фоне минеральных удобрений было на $15-20 \%$ выше, чем в загрязненном контроле, что свидетельствует о благоприятном воздействии мелиоранта на стрессоустойчивость газонных трав.

Ключевые слова: тяжелые металлы, кадмий, загрязнение, газонные экосистемы, экологические функции, кремний, мелкоделяночный опыт, сахара, стрессоустойчивость 